\section{Validation of an Information Asymmetry Scale in the Portuguese Real Estate Market}

\author{
Fernando Tavares ${ }^{1}$ (i) \\ Eulália Mota Santos ${ }^{2}$
}

\begin{abstract}
Purpose - The motivation to study the information asymmetry in the real estate market comes from the fact that this market is far from being efficient and perfect, and buying a house is, for most families, the biggest deal of their lives. This paper aims to validate a scale that evaluates the information asymmetry in the Portuguese real estate market.
\end{abstract}

Theoretical framework - During the sales negotiation process, estate agents exhibit the positive aspects of the house, as well as its amenities and qualities, and camouflage the least positive aspects of the deal. Finding both the positive and the negative aspects is crucial.

Design/methodology/approach - To collect the sample, an instrument based on a questionnaire survey was used, which analyses the information asymmetry in the real estate market and the sociodemographic profile of estate agents in Portugal. The sample is composed of 350 commercial delegates from the three biggest real estate mediation companies in the Portuguese market.

Findings - The results show that the scale for the information asymmetry in the Portuguese real estate market is composed of six factors, which present adequate levels of validity and reliability: negative externalities, possibilities of making a deal, housing quality, service areas, proximity to businesses, and positive externalities.

Practical \& social implications of research - This study is expected to contribute to improving the scientific knowledge on the real estate market, and to enhancing the information transmitted by estate agents to their future clients.

Originality/value - In Portugal, there is no study with such depth about this topic of research. The validation of the information asymmetry scale in the Portuguese real estate market represents a breakthrough in the knowledge in this area.

Keywords - information asymmetry, real estate market, housing demand, housing location, real estate externalities.

1. ISCET - Higher Institute of Business and Tourism, Porto, Portugal.

2. Polytechnic of Leiria, Leiria, Portugal.

How to cite:

Tavares, Fernando., Santos, Eulália Mota., (2021). Validation of an Information Asymmetry Scale in the Portuguese Real Estate Market. Revista Brasileira de Gestão de Negócios, 23(4), p.586-599.
Received on:

05/21/2020

Approved on:

04/15/2021

Responsible Editor:

Prof. Dr. Sebastian Molinillo

\section{Evaluation process:}

Double Blind Review

\section{Reviewers:}

Alcides Barrichello; Ana Paula Monteiro

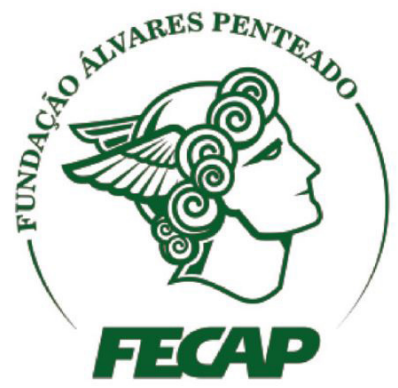

Revista Brasileira de Gestáo de Negócios

https://doi.org/10.7819/rbgn.v23i4.4136 


\section{Introduction}

Although it is not studied much in Portugal, because of its relevance, information asymmetry has a strong impact on real estate deals. The information asymmetry in the real estate market can be defined as the difference in the level of information, such as the disparity of information about an immovable property, between the seller and the buyer. That difference in information and knowledge can derive not only from a lack of liquidity in the market but also from awareness of the physical characteristics and the quality of housing. In the real estate market, the seller usually has better and more information than the buyer.

According to Statistics Portugal (2018), since 2012 (76,398 dwellings were sold in 2012), the number of dwellings sold in Portugal has been growing and, in 2018, 178,691 dwellings were sold. Regarding 2017 (153,292 dwellings were sold), 16.6\% growth occurred. The number of transactions since 2012 is greater in the category of existing dwellings, in comparison to the category of new dwellings. In 2018, 152,212 existing dwellings and 26,479 new dwellings were sold. The value of house sales in Portugal in 2018 was 24.1 billion euros (24.4\% more than in 2017), which is equivalent to $12 \%$ of GDP.

The asymmetry in the real estate market may derive from the market's illiquidity, from adverse selection, from the players' reputation, and from the depreciation of real estate, which is due not only to its physical but also its functional usage, as the shape and quality of constructions are continuously changing. The buyer must obtain knowledge and information by seeking real estate promotors and companies that have a good reputation. Estate agents play a crucial role in reducing the impact of information asymmetry.

In a review of the literature about information asymmetry in the real estate market, Tavares, Moreira and Pereira (2012) categorized the studies on this topic in four subtopics: the price distortion in the real estate market, the adverse selection, the predictability of returns, and the depreciation of real estate. In recent years, the authors have addressed the asymmetry caused by the level of information. This can hail from the difference in the knowledge and information between buyers and sellers about prices, the energy efficiency of properties, their depreciation, and the participation of sellers in the business, among others.
This study aims to validate a scale to assess the information asymmetry in the Portuguese real estate market and to analyse which factors contribute most to information asymmetry. To do so, this article is structured into five parts. After this introduction, the literature review is presented. In the third part, the methodology is shown, describing the collected sample, the data collection instruments, and the statistical procedures. The fourth part presents the results, and last but not least, in the fifth part, the conclusions of the work are laid out.

\section{Literature Review}

As Ben-Shahar and Golan (2019) understand, the finer the available information, the better for buyers and sellers, and the markets that most benefit from that are those where the levels of education, income, and socioeconomic conditions are lower.

Canepa and Chini (2016) mention that during expansion periods, house prices increase exponentially, and during contraction periods, they decrease logarithmically. Therefore, contractions occur for longer periods than expansions. After the subprime global financial crisis, there was a growing consensus that the real estate sector played a stabilizing role in the economy.

Wang et al. (2020) conclude that, in China, the volatility of house prices derives from the impact of monetary policies. An optimistic macro-analysis leads to positive house price volatility and that volatility tends to increase with political uncertainty. Thus, the authors conclude that when political uncertainty is high, the macro-environmental impact on house prices is also high. Also regarding prices, André, Gupta and Mwamba (2019) conclude that various reasons may explain house price asymmetry, including the non-linearity of its determinants and behavioural responses, in particular those attached to the value of constructions and aversion to losses.

The authors Wit and Klaauw (2013) show that reductions in the price list significantly increase the risk of selling, possibly with substantial losses. In a market with information asymmetry, the signals of abrupt drops in prices do not add any information.

According to Cheng, Liu and Liu (2019), house prices often have restrictions, so when studying prices, one must take into consideration whether there was pressure to sell the property, what the planned deadline to sell was, and what the main reasons for the definition of the deadline to sell were. Puy, Ary and Shi (2020) discovered 
that house prices increased more disproportionately in the neighbourhoods (in the USA) with a high concentration of populations from countries in crisis, which the authors interpret as (indirect) evidence of the effect on local house prices caused by foreign buyers.

Levy, Bentham and Cheung (2020) conclude that the framing effects in the real estate market are asymmetric and that asymmetry is a result of familiarity with the market. The study's results show that pessimistic framing leads buyers to forecast sharp drops in house prices, whereas optimistic framing leads buyers to predict a short increase in prices. This study reveals that downturns in the real estate market can be sharpened and extended if there is a pessimistic perspective in the markets. The framing effects in the market's ups and downs are clear, and such effects can lead to asymmetric house price movements. Pessimistic or optimistic framing by individuals regarding house prices reflects their aversion to loss. On the other hand, pessimistic or optimistic framing by individuals will be exaggerated by the limited rationality of house buyers.

Feelings are an important factor in the decision to buy or to sell a dwelling, according to Saydometov, Sabherwal and Aroul (2020). The authors built an index of feelings based on Google Trends and observed that an increase in negative feelings about the next month predicts a drop in the return of the housing index in the next month. They also found evidence that the sentiment index has a forecasting ability of up to 3 months.

For Cheng, Lin and Liu (2019), there is a fundamental difference between real estate and financial assets. In the real estate market, the transaction price is a function of the property's value and the seller's influence, whereas in the financial market the prices are believed to capture all the information related to the value. This observation by itself reveals the existence of information asymmetry. Their study reveals that, due to the heterogeneity of sellers and to their restrictions and personal preferences, prices can be heavily distorted. They also highlight that when sales prices are identical for different properties, this reveals differences between sellers.

\section{I. Quality of construction, utilization, and location of housing}

Quality of construction was studied by BenShahar and Golan (2019), who believed that house prices vary depending on the quality of construction. In a study about information asymmetry, Kurlat and
Stroebel (2015) conclude that, in the real estate market, sellers are better informed about the real value of the assets than buyers, to which is added the possibility of information heterogeneity between buyers and sellers. There are more informed sellers with a bigger offer, more price elasticity, and a greater capability to forecast future prices. The authors understand that better-informed buyers buy houses that rise in value, because the buyers, as the owners of the houses, have more information on important characteristics of the neighbourhood, and that is an important aspect regarding asymmetry. Also, Levitt and Syverson (2008) concluded that the estate agent is better informed than the buyer about transaction values and the market situation. When an estate agent sells his/ her own house, it is more expensive and has been on the market for more than ten days on average; that is, sellers sometimes induce their clients into selling too fast at a lower price.

In his study about manipulation by estate agents, Hong (2020) verified that the properties of agents have a higher price than the general price listings and that estate agents manipulate clients when they present those house listings. Hong (2020) concluded that manipulation in the presentation of dwellings explains $70 \%$ of the difference in the sale price premium between properties in general and the properties of agents. The author suggests that agents must be disciplined to avoid these situations, so that price listings can be more serious. The author mentions that removing this kind of manipulation by agents can lead to an increase in the premiums of estate agents and the minimum level of effort on their part to improve the available information on properties.

The authors Aydin, Brounen and Kok (2018) investigated how private investors capitalize on energy efficiency in the real estate market, and the impact of the emission of an energy performance certificate. For the authors, most of the literature on the capitalization of energy efficiency in the real estate market suffers from a disadvantage, which is the potential bias that results from not mentioning the unobservable housing characteristics with the energy efficiency measurements. The results of the study of Aydin, Brounen and Kok (2018) indicate that energy efficiency is capitalized on in the prices of immovable properties. In their study, the authors documented that for the Dutch market, if the energy requirements of a house are reduced by $10 \%$, the price of that house rises by approximately $2.2 \%$. Their study also states that there is a bigger capitalization for houses sold with an energy 
performance certificate. This paper by Aydin, Brounen and Kok (2018) mentions that besides the direct returns due to less expenditure on energy, the improvements in energy efficiency impact the transaction costs, regardless of the existence or absence of an energy certificate.

\subsection{Possibilities the estate agent has of making a deal in the housing market}

When strong financial incentives to buy housing exist, the information asymmetry is greater, according to Donner and Kopsch (2018). Stroebel (2016) also mentions that real estate promotors generally cooperate with mortgage lenders, by giving information on the construction quality of houses, which serves as a warranty. By conditioning interest rates to that information, lenders expose the market to adverse selection. In ventures where lenders (investors) form part of the promotion of an immovable property, bigger returns on investment are presented, and investors have a lower probability of going bankrupt.

For Qiu, Tu and Zhao (2020), the heterogeneity of house buyers influences the level of demand and the negotiating power to strike a good deal. The study's results show that information asymmetry, the anchoring effect (the effect of relying too heavily on initial information, which leads to drawing conclusions based on a single point of reference), and demographic characteristics affect the probability of buyers striking a good deal. Donner and Kopsch (2018) highlight that income and education level hurt the power of persistence in negotiations. The authors mention that the asymmetry and anchoring effects are different between buyers of different ages. Older buyers usually deal with the anchoring effect better and thus present greater possibilities of ensuring a good deal. For the authors, there is an information gap between sellers and buyers. Agarwal, He, Sing and Song (2019) found factors that imply that real estate agents exploit their information advantage by buying houses for their usage, paying approximately $2.54 \%$ less for their houses, in comparison to other houses bought by non-estate agent buyers. They concluded that estate agents have more information advantages in environments with less information. The authors also found that sellers who are also estate agents have a lower probability of negotiating with well-informed house buyers (it is inferred that they prefer to negotiate with buyers who are less informed about a deal). On balance, there is segmentation in the market, in which sellers who are estate agents have a higher probability of selling to buyers who are also estate agents, which is in line with the conclusions of Garmaise and Moskowitz (2004) and Levitt and Syverson (2008). Agarwal et al. (2019) demonstrated that buyers who are agents buy their houses at lower prices in comparison to other non-agent buyers.

Garmaise and Moskowitz (2004) say that proximity between participants in the market supports the prediction that less-informed agents participate less in the market, and that, inversely, better-informed agents are sought to mitigate information asymmetries. For the authors, in the real estate market, there is a negative correlation between the buyer and long distances. They also mention that the participants in the market are financed in different ways, as a way to lessen information problems in the real estate market.

According to Li and Chau (2019), non-local (foreign) buyers, motivated by a reduction in the information asymmetry of new properties, tend to buy those types of properties; otherwise, they would pay a higher price than local buyers in the used properties market, for similar dwellings. The sellers of new dwellings want higher commissions to pay for their efforts to reduce the information asymmetry, especially when the information asymmetry problems are serious. Non-local buyers suffer from greater information asymmetry, and the authors state that they do not have proper support when they buy a house. Li and Chau (2019) observe that non-local buyers are often willing to pay for higher commissions, with the aim of reducing that information asymmetry.

\subsection{Room dimensions and amenities}

As far as the different dimensions and rooms of an apartment are concerned, Bui (2020) concluded that the prices of apartments are positively affected by the presence of a balcony, a pool, proximity to a shopping centre, and the possibility of renting. Bui (2020) states that these conclusions are valuable for apartment designers since they might offer better solutions to increase the value of the apartments and meet the customers' demands. In addition, Mohammadi (2010) states that the different rooms of the house impact its natural ventilation. In the study, it is concluded that the introduction of a balcony increases the commercial value of a property, because the dwelling's natural ventilation improves. Also, the size of the windows, besides providing more daylight, can help to direct air into the interior. 
Negative externalities harm a property's location since they put people off and make them seek a residence away from such places. These externalities include proximity to motorways, places with undesirable landscapes and odours, overhead power lines, sanitary landfills, and delinquency. Other negative externalities include highly polluted areas with coal-fired power plants, nuclear power plants, oil refineries, and other contaminating activities that affect the population's quality of life and property values and rights (Chen, Li, 2017; Jensen et al., 2018). In a study about the real estate market, Tavares (2011) described the factors that result from the preferences for rooms and divided them into supporting areas (sunroom, balcony, and kitchen areas) and proper housing areas (bedrooms, living rooms, and bathrooms). According to the author, these two factors are decisive when choosing a house, and therefore, are an object of special care when estate agents present them.

Carlino and Saiz (2019) understand that amenities and urban beauty spots are perceived as ways of improving the quality of life of urban dweller. Parks, museums, leisure areas, and public buildings with attractive architecture (public transportation stations, courts, municipal buildings, etc.) are some examples that can be mentioned. Nowadays, urban citizens value leisure amenities. According to Carlino and Saiz (2019), the most highly valued amenities are proximity to the ocean, panoramic views, historical neighbourhoods, cultural and architectonical landmarks, and recreational opportunities.

For Nasser (2017), some of the aspects with a positive impact on housing value are proximity to a subway station, parks, green areas, and landmarks. With a negative impact on housing value, the author mentions areas with higher crime rates and the incidence of vandalism. The author also verified that housing prices are lower in densely populated areas.

In coastal communities, proximity to the sea and views tend to compensate for the expected costs of storms, according to Walls, Magliocca and McConnel (2018). The authors state that the impacts depend on the region because positive externalities and the risks of storms and other bad weather vary from region to region. It was concluded that the amenities and risks of storms are capitalized in the value of the land.

\section{Methodology}

\section{I. Sample and Data Collection}

To facilitate the data collection process that was carried out between March and November 2019, a questionnaire was created on Google Forms and a link was sent via email to 2500 delegates of the three biggest real estate mediation companies in Portugal (RE/MAX, ERA, and CENTURY 21), whose addresses were in a database that was provided after the companies accepted to participate in the study. Initially, different companies from the real estate market were invited to participate in the study, but some declined the invitation. The emails were sent to the participants with a short introductory summary, where the study's objectives were defined, and the anonymity and confidentiality of the information given were insured.

The three companies, RE/MAX, ERA, and CENTURY 21, are currently part of the biggest international real estate franchising network. RE/MAX (Real Estate Maximum) was founded in 1973 in the United States of America (USA), and it currently operates in over 85 countries. It was established in Portugal in 2000 and already has 320 agencies and employs over 7000 estate agents. ERA (Electronic Realty Associates) was founded in the USA in 1971 and is now present in 50 countries. ERA was, in 1998, the pioneer of real estate franchising in Portugal, and currently has approximately 200 agencies distributed all over the country and more than 2200 estate agents. CENTURY 21 was founded in the USA in 1971, and is currently present in more than 88 countries. It has been in Portugal since 2005 and has roughly 120 agencies distributed across the whole country with nearly 1400 estate agents.

Of the 2500 emails sent, 320 were found to be redundant (the emails were sent back). 452 answers were obtained, but 102 questionnaires were annulled because they were incomplete. Thus, in this study, the target population was the 2180 commercial delegates that were contacted from the three biggest real estate mediation companies in Portugal and the sample was composed of 350 delegates, corresponding to a response rate of approximately $16 \%$. According to Schumacker and Lomax (2004), the recommended sample size to apply structural equation modelling is from 250 to 500 , which is why the size of the sample is considered adequate. 


\subsection{Data collection instruments}

The methodological approach utilized in this study is quantitative. The instrument used is composed of two parts. The first one involves the sociodemographic profile of the respondents (gender, age, marital status, education level, whether the job is a part-time or a full-time job, the number of years of experience as an estate agent). The second part analyses the information asymmetry in the real estate market, that is, the level of information given by the estate agents to potential buyers and the relationship established during the purchase. To measure the information asymmetry in the real estate market, the 56 items presented in Table 1 were utilized, which were derived from the study of Tavares et al. (2012), where exploratory research was carried out.

The items related to the construction quality, utilization, and location of the housing (items It1 to It36) were measured on a five-point Likert scale that ranges from $1-$ Not very relevant $5-$ Very relevant. The items related to the possibilities the estate agent has of making a deal in the housing market (items It37 to It48) were evaluated on a five-point Likert scale that goes from 1 Little preference to 5 - High preference. The remaining items are related to the level of information to be given by the estate agents about the size of the rooms (items It 49 to It56), which were measured on a five-point Likert scale that varies between 1 - Not very important and 5 - Very important. Likert scales are commonly used

Table 1

\section{Items that Evaluate the Information Asymmetry in the Real Estate Market}

\begin{tabular}{|c|c|c|}
\hline \multicolumn{3}{|c|}{ Construction quality, utilization, and location of housing } \\
\hline It1- Construction company’s reputation & \multicolumn{2}{|c|}{ It19- Existence of exterior green areas } \\
\hline It2- Processes used during the construction & \multicolumn{2}{|c|}{ It20- Future taxes to pay for the house } \\
\hline It3- Construction materials and their durability & \multicolumn{2}{|c|}{ It21- Traffic noise } \\
\hline It4- Climatization of housing & \multicolumn{2}{|c|}{ It22- Degraded park } \\
\hline It5-Architectural project & \multicolumn{2}{|c|}{ It23- Sanitary landfill } \\
\hline It6- Building safety project & \multicolumn{2}{|c|}{ It24- Overhead power lines } \\
\hline It7- Comfort of housing & \multicolumn{2}{|c|}{ It25-Contaminated surrounding lands } \\
\hline It8- Efficiency and maintenance of the facilities & \multicolumn{2}{|c|}{ It26- Greater than average air pollution } \\
\hline It9- Structural safety of the building & \multicolumn{2}{|c|}{ It27-Solid waste incineration } \\
\hline It10- Common areas of the building & \multicolumn{2}{|c|}{ It28- Wastewater treatment plant } \\
\hline It11- Easiness to park outside & \multicolumn{2}{|c|}{ It29- Eolic park } \\
\hline It12- Existence of lift & \multicolumn{2}{|c|}{ It30- Sea views } \\
\hline It13- Staircase location & \multicolumn{2}{|c|}{ It31- Mountain views } \\
\hline It14- Energy costs of the house & \multicolumn{2}{|c|}{ It32- Views of a square/street } \\
\hline It15- Rubbish collection & \multicolumn{2}{|c|}{ It33- Proximity to a pharmacy } \\
\hline It16- Condominium costs & \multicolumn{2}{|c|}{ It34- Proximity to a bar/restaurant } \\
\hline It17- Exact age of the house & \multicolumn{2}{|c|}{ It35- Proximity to a bank } \\
\hline It18- Material used in the building's roof & \multicolumn{2}{|c|}{ It36- Proximity to a supermarket } \\
\hline \multicolumn{3}{|c|}{ Possibilities the estate agent has of making a deal in the housing market } \\
\hline It37- With other estate agents & \multicolumn{2}{|c|}{ It $45-$ With clients that resort to credit } \\
\hline It38- Of a used house & \multicolumn{2}{|c|}{ It46- With clients that do not resort to credit } \\
\hline It39- Of a new house & \multicolumn{2}{|c|}{ It47- With clients that know the market } \\
\hline It40- With clients that are looking for a cheap house & \multicolumn{2}{|c|}{ It48- With young clients (first purchase) } \\
\hline \multicolumn{3}{|c|}{ It41- With clients that are looking for a high-quality house } \\
\hline \multicolumn{3}{|c|}{ It42- With middle-aged clients (it is not the first time they are buying a house) } \\
\hline \multicolumn{3}{|c|}{ It43- With people that live near the area of purchase } \\
\hline \multicolumn{3}{|c|}{ It44- With people that live far from the property they want to buy } \\
\hline \multicolumn{3}{|c|}{ Room sizes } \\
\hline It49- Area of the bedrooms & It52- Area of the balcony & It55- Area of the garage \\
\hline It 50 - Area of the bathrooms & It53-Area of the kitchen & It56-Area of the storage space \\
\hline It 51 - Area of the living room & It54- Area of the sunroom & \\
\hline
\end{tabular}

Source: Own elaboration. 
in questionnaires and were initially developed by Rensis Likert in 1932 (Dalmoro \& Vieira, 2013).

\subsection{Statistical procedures}

To characterize the profile of the estate agents, descriptive statistics were used in the IBM SPSS Statistics 25 software.

In accordance with Kline (2015) and Marôco (2018), the sensitivity of the items was evaluated using the skewness $(|\mathrm{Sk}| \leq 3)$ and kurtosis coefficients $(|\mathrm{Ku}| \leq$ 7). The factor validity of the model was assessed using the techniques of exploratory and confirmatory factor analysis. To ascertain the suitability of applying exploratory factor analysis (EFA) to the sample under study, the KaiserMeyer-Olkin sampling adequacy test (a KMO value greater than 0.8 reveals a good sample fit) and Bartlett's sphericity test $(p<0.05)$ were used (Pestana \& Gageiro, 2014). In the EFA, to extract the factors, the principle components method was used, followed by varimax rotation, and to determine the minimum number of factors to retain, Kaiser's criterion was used (eigenvalues greater than 1). Factor loadings greater than 0.50 are considered satisfactory because they present less than $25 \%$ variance (Hair, Black, Babin, \& Anderson, 2014).

Next, the fit of the structure that emerged from the EFA was tested by applying confirmatory factor analysis (CFA), using the IBM SPSS Amos software. In the CFA, the maximum similarity method of estimation was used, and the following fit quality indices were used: the quotient of the chi-squared statistic divided by the degrees of freedom $\left(\chi^{2}\right)$ $d f$ ) in the interval $[1,2]$ indicates a good fit, a GFI (goodness of fit index) and CFI (comparative fit index) greater or equal to 0.9 are indicators of a good fit, and a RMSEA (root mean square error of approximation) less than or equal to 0.05 indicates a very good fit (Kline, 2015; Marôco, 2014). To evaluate the model's parsimony, the MECVI (modified expected cross-validation index) comparative fit index and the chi-squared fit difference test were used.

The reliability of the factors was evaluated using Cronbach's alpha (Marôco \& Garcia-Marques, 2006) and the composite reliability (Fornell \& Larcker, 1981). To be considered acceptable, these measures must present values greater than 0.7 .

The convergent validity was estimated by the AVE (average variance extracted), which must present values greater than 0.5 to indicate adequate convergent validity. To analyse the discriminant validity, three parameters were used: AVE, MSV (maximum shared variance), and ASV (average shared variance), and it was considered that the AVE value must be greater than the values of the MSV and ASV and that the square root of the AVE value must be greater than the inter-factor correlations (Hair et al., 2014).

\section{Results}

\section{I. Sample characterization}

The sample under study was composed of 350 individuals, aged between 18 and 72 years old with an average age of 42 years ( $\mathrm{SD}=9.88)$, mostly composed of men $(n=209,59.7 \%)$. Regarding marital status, $61.8 \%$ were married or lived in a common-law marriage, $21.7 \%$ were separated, divorced, or widowed, and $16.6 \%$ were single. Regarding education level, $49.1 \%$ had a college degree, $46.9 \%$ had only completed secondary school, and $4.0 \%$ had only completed basic education. Regarding working as an estate agent, $92.3 \%$ worked full-time in the field, and $7.7 \%$ worked part-time. On average, the estate agents had worked in the field for approximately five years $(\mathrm{SD}=4.08)$, and the person that had been working as for longest started doing so 27 years ago.

\subsection{Exploratory Factor Analysis}

The application of the exploratory factor analysis technique to the 56 items in Table 1 resulted in the successive elimination of the items that present communality values inferior to 0.5 and the items that were simultaneously saturated in more than two dimensions.

After this analysis, Bartlett's sphericity test and the KMO index for the resulting 44 items ( $=10497.581$, $p<0.001, \mathrm{KMO}=0.892)$ presented a good sample fit to apply the EFA (Pestana \& Gageiro, 2014).

Table 2 presents the factor loadings and communalities matrix of the 44 items retained to make up the scale for information asymmetry in the real estate market. Eight factors were retained, which together explain $67.84 \%$ of the total variance.

The first factor explains $15.94 \%$ of the variance and because of the variables that contribute to explain that factor, it was called Negative Externalities. Since people tend to shy away from these types of externalities, estate agents understand that potential buyers should be given information related to aspects that may negatively influence the purchase of a given dwelling (Chen \& Li, 2017; Jensen et al., 2018; Nasser, 2017). 
Table 2

Factor loadings and communalities matrix of information asymmetry in the real estate market

\begin{tabular}{|c|c|c|c|c|c|c|c|c|c|}
\hline & \multicolumn{8}{|c|}{ Factor } & \multirow{2}{*}{$h^{2}$} \\
\hline & 1 & 2 & 3 & 4 & 5 & 6 & 7 & 8 & \\
\hline It27 & 0.936 & & & & & & & & 0.894 \\
\hline It 25 & 0.919 & & & & & & & & 0.859 \\
\hline It26 & 0.894 & & & & & & & & 0.838 \\
\hline It 23 & 0.887 & & & & & & & & 0.808 \\
\hline It 24 & 0.887 & & & & & & & & 0.800 \\
\hline It 28 & 0.884 & & & & & & & & 0.820 \\
\hline It 22 & 0.831 & & & & & & & & 0.731 \\
\hline It 21 & 0.793 & & & & & & & & 0.664 \\
\hline It 29 & 0.672 & & & & & & & & 0.577 \\
\hline It 48 & & 0.838 & & & & & & & 0.710 \\
\hline It42 & & 0.838 & & & & & & & 0.714 \\
\hline It38 & & 0.827 & & & & & & & 0.711 \\
\hline It39 & & 0.817 & & & & & & & 0.702 \\
\hline It 43 & & 0.797 & & & & & & & 0.668 \\
\hline It 44 & & 0.803 & & & & & & & 0.672 \\
\hline It45 & & 0.753 & & & & & & & 0.616 \\
\hline It 40 & & 0.754 & & & & & & & 0.603 \\
\hline It41 & & 0.703 & & & & & & & 0.549 \\
\hline It47 & & 0.677 & & & & & & & 0.536 \\
\hline It54 & & & 0.853 & & & & & & 0.757 \\
\hline It 50 & & & 0.778 & & & & & & 0.620 \\
\hline It56 & & & 0.774 & & & & & & 0.667 \\
\hline It52 & & & 0.738 & & & & & & 0.587 \\
\hline It55 & & & 0.703 & & & & & & 0.644 \\
\hline It53 & & & 0.690 & & & & & & 0.537 \\
\hline It8 & & & & 0.775 & & & & & 0.660 \\
\hline It9 & & & & 0.721 & & & & & 0.662 \\
\hline It 10 & & & & 0.686 & & & & & 0.604 \\
\hline It6 & & & & 0.680 & & & & & 0.612 \\
\hline It 4 & & & & 0.636 & & & & & 0.501 \\
\hline It7 & & & & 0.602 & & & & & 0.551 \\
\hline It 14 & & & & 0.551 & & & & & 0.527 \\
\hline It35 & & & & & 0.854 & & & & 0.777 \\
\hline It34 & & & & & 0.782 & & & & 0.686 \\
\hline It33 & & & & & 0.775 & & & & 0.767 \\
\hline It36 & & & & & 0.762 & & & & 0.694 \\
\hline It 30 & & & & & & 0.828 & & & 0.758 \\
\hline It31 & & & & & & 0.780 & & & 0.795 \\
\hline It32 & & & & & & 0.531 & & & 0.540 \\
\hline It 51 & & & & & & & 0.828 & & 0.748 \\
\hline It 49 & & & & & & & 0.725 & & 0.714 \\
\hline It 1 & & & & & & & & 0.836 & 0.744 \\
\hline It 2 & & & & & & & & 0.607 & 0.651 \\
\hline It3 & & & & & & & & 0.536 & 0.577 \\
\hline Eigenvalues & 7.015 & 6.412 & 4.025 & 3.967 & 3.122 & 1.934 & 1.695 & 1.682 & \\
\hline $\begin{array}{l}\% \text { variance } \\
\text { explained }\end{array}$ & 15.943 & 14.572 & 9.149 & 9.015 & 7.096 & 4.395 & 3.851 & 3.822 & \\
\hline $\begin{array}{l}\text { Cronbach's } \\
\text { alpha }\end{array}$ & 0.960 & 0.933 & 0.873 & 0.841 & 0.856 & 0.700 & 0.720 & 0.714 & \\
\hline
\end{tabular}

Source: Own elaboration. 
The second factor explains $14.57 \%$ of the variance and is composed of variables that analyse the estate agents' preferences for making deals with the potential clients, and it is called Possibilities of a Deal (Agarwal et al., 2019; Levitt \& Syverson, 2008; Li \& Chau, 2019).

The third factor explains $9.15 \%$ of the variance and assesses the importance of the information that estate agents give to potential buyers about a dwelling's service/ storage areas, which is why it is called Service Areas (Bui, 2020; Tavares, 2011).

The fourth factor is called Housing Quality and explains $9.02 \%$ of the variance. The variables of this factor are related to the level of information that estate agents give to potential buyers about aspects relate to the quality of the dwelling (Ben-Shahar \& Golan, 2019; Kurlat \& Stroebel, 2015).

The fifth factor is Proximity to Businesses and explains $7.10 \%$ of the variance. Proximity to businesses presents both positive and negative aspects, and consequently, estate agents understand that this information should be provided to potential buyers (Qiu, Tu, \& Zhao, 2020; Carlino \& Saiz, 2019; Nasser, 2017).

Factor 6 explains $4.40 \%$ of the variance and is related to the level of information about a property's positive externalities that estate agents decide to provide because people tend to be attracted to these types of externalities (Carlino, Saiz, 2019; Walls, Magliocca, McConnel, 2018). Therefore, this factor will be called Positive Externalities.

The seventh factor explains $3.85 \%$ of the variance and is only composed of two items that are related to the level of information the estate agents give about a dwelling's leisure or rest areas. It is called Rest or Leisure Areas (Bui, 2020; Carlino \& Saiz, 2019).

Finally, factor 8 is related to the level of information the estate agents give about the reputation of a dwelling's construction quality (Ben-Shahar \& Gola, 2019; Kurlat \& Stroebel, 2015; Stroebel, 2016). This factor is called Reputation for Quality and explains 3.82\% of the variance.

All the dimensions of the scale of determining factors in the choice of a dwelling present Cronbach's alpha values greater than 0.70 and, according to Pestana and Gageiro (2014), the internal consistency is considered acceptable.

The dimensions found through the EFA in this study agree with the ones found in the study of Tavares, Moreira and Pereira (2013), with small differences: in this study, the items "With other estate agents" (It37) and "With clients that do not resort to credit" (It46) were excluded from the "Possibilities of a Deal" factor and the "Views of a square/street" item was included in the "Positive Externalities" factor.

Note that the EFA resulted in a factor (factor 7) with only two items, which could be related to the dwelling's rest or leisure areas. This factor was not considered in the confirmatory factor analysis, because according to Hair et al. (2014), at least three items are necessary to determine the formation of a factor. Regarding factor 8, it presents two items with low factor loadings ( 0.536 and 0.607$)$ and it is verified that by eliminating the items of factor 7 , some items in factor 8 start to saturate simultaneously in two factors.

\subsection{Confirmatory Factor Analysis}

The structure obtained through the EFA was subjected to the application of the confirmatory factor analysis and the fit indices revealed an acceptable fit $\left(\chi^{2}=1936.816, d f=874, \chi^{2} / d f=2.216, p<0.001\right.$, $\mathrm{GFI}=0.794, \mathrm{CFI}=0.894, \mathrm{RMSEA}=0.059, \mathrm{PCLOSE}=0.000$, MECVI = 6.313). The modification indices were analysed and the model was simplified. The factors Reputation for Quality (Items It1, It2, and It3) and Rest or Leisure Areas (Items It 49 and It51) were eliminated, as well as items It4 (Climatization of Housing), It7 (Comfort of Housing), It29 (Eolic Park), and It47 (With clients that know the market), since they were correlated with items from other factors. Besides this reformulation, trajectories were added between some residuals since they were correlated, and the model presented in Figure 1 was derived, composed of six dimensions: Negative Externalities (NE), composed of 8 items (It21, It22, It23, It24, It25, It26, It27 and It28); Possibilities of a Deal (PD), formed of 9 items (It38, It39, It40, It41, It42, It43, It44, It45 and It48); Service Areas (SA), formed of 6 items (It50, It52, It53, It54, It 55 and It56); Housing Quality (HQ), which comprises 5 items (It6, It8, It9, It10 and It14); Proximity to Businesses (PB), formed of 4 items (It33, It34, It35 and It36); and Positive Externalities (PE), composed of 3 items (It30, It31 and It32).

The standardised factor loadings of all items present values greater than 0.5 , as the minimum factor loading is 0.59 , and the individual reliabilities present values greater than 0.25 , as the lowest one is equal to 0.34. The fit indices of the model in Figure 1 revealed a good quality of fit $\left(\chi^{2}=991.551, d f=538, \chi^{2} / d f=1.843\right.$, $p<0.001, \mathrm{GFI}=0.859, \mathrm{CFI}=0.947, \mathrm{RMSEA}=0.049$, PCLOSE $=0.606, \mathrm{MECVI}=3.429)$. The quality of fit of the simplified model is significantly superior to the 


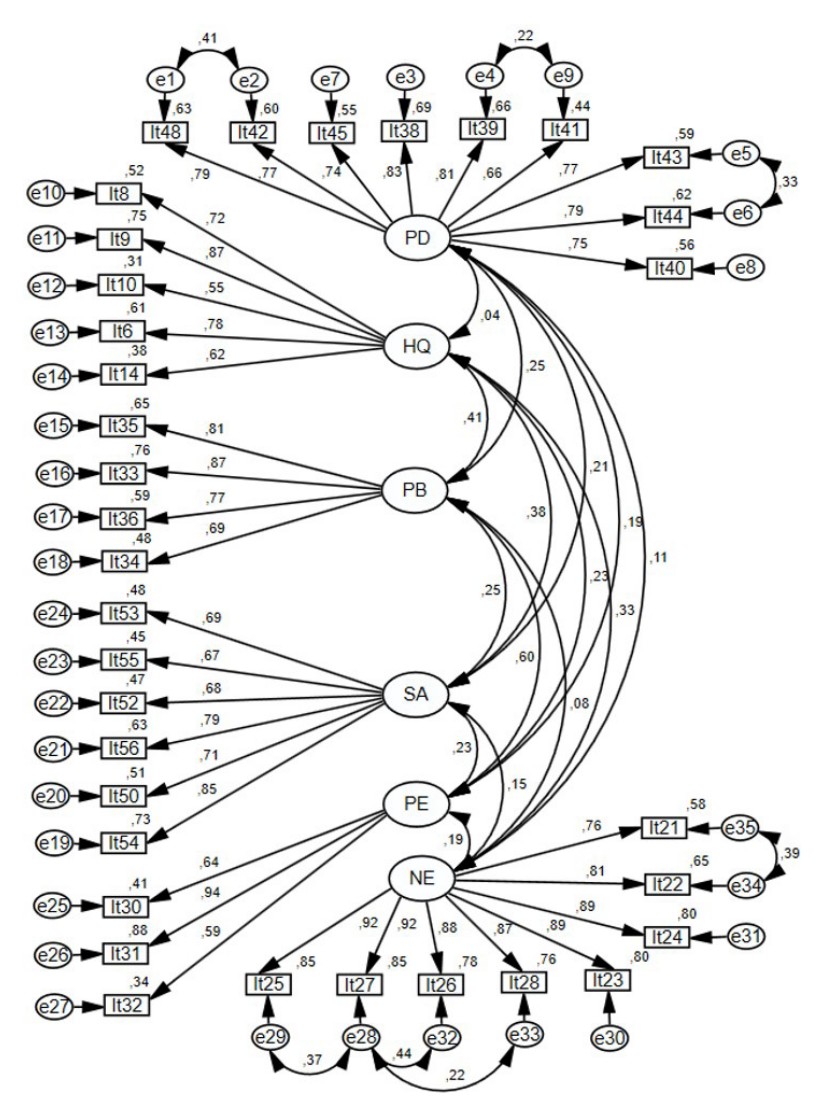

Figure 1. Model to Measure the Information Asymmetry in the Real Estate Market

Source: Own elaboration. quality presented by the model that was initially applied to the sample $\left(\chi^{2}=945.265>347.769\right)$, and the MECVI value is considerably better.

In the model presented above, the items "Contaminated surrounding lands" (It25) and "Solid waste incineration" (It27) are the ones that most contribute to the factor Negative Externalities. The items "Of a used house" (It38) and "Of a new house" (It39) are the ones that most contribute to the factor Possibilities of a Deal. The items "Area of the sunroom" (It54) and "Area of the storage space" (It56) are the ones that most contribute to the factor Service Areas. The items "Structural safety of the building" (It9) and "Building safety project" (It6) are the items that most contribute to the factor Housing Quality. The items "Proximity to a pharmacy" (It33) and "Proximity to a bank" (It35) are the ones that most contribute to the factor Proximity to Businesses, and the item "Mountain views" (It31) is the one that most contributes to the factor Positive Externalities.

\subsection{Reliability and Convergent and Discriminant validity}

From observing Table 3, it is concluded that the factors of the information asymmetry in the real estate market present Cronbach's alpha and composite

Table 3

\section{Reliability and Convergent and Discriminant Validity}

\begin{tabular}{|c|c|c|c|c|c|c|}
\hline & \multicolumn{2}{|c|}{ Cronbach's alpha } & $C R$ & $A V E$ & $M S V$ & $A S V$ \\
\hline Negative & \multicolumn{2}{|c|}{0.963} & 0.962 & 0.758 & 0.106 & 0.036 \\
\hline \multicolumn{7}{|l|}{ Externalities (NE) } \\
\hline $\begin{array}{l}\text { Possibilities of a Deal } \\
\text { (PD) }\end{array}$ & \multicolumn{2}{|c|}{0.932} & 0.929 & 0.593 & 0.062 & 0.031 \\
\hline $\begin{array}{l}\text { Housing Quality } \\
\text { (HQ) }\end{array}$ & \multicolumn{2}{|c|}{0.832} & 0.838 & 0.514 & 0.165 & 0.095 \\
\hline Service Areas (SA) & \multicolumn{2}{|c|}{0.873} & 0.876 & 0.542 & 0.146 & 0.065 \\
\hline $\begin{array}{l}\text { Proximity to } \\
\text { Businesses (PB) }\end{array}$ & \multicolumn{2}{|c|}{0.856} & 0.867 & 0.621 & 0.360 & 0.131 \\
\hline \multirow{3}{*}{$\begin{array}{l}\text { Positive Externalities } \\
\text { (PE) }\end{array}$} & \multicolumn{2}{|c|}{0.700} & 0.775 & 0.545 & 0.360 & 0.108 \\
\hline & \multicolumn{6}{|c|}{ Correlations } \\
\hline & $\mathrm{NE}$ & PD & HQ & SA & PB & PE \\
\hline $\mathrm{NE}$ & 0.871 & & & & & \\
\hline $\mathrm{PD}$ & 0.106 & 0.770 & & & & \\
\hline HQ & $0.325^{* * *}$ & 0.039 & 0.717 & & & \\
\hline SA & $0.150^{*}$ & $0.208^{* * *}$ & $0.382 * * *$ & 0.736 & & \\
\hline $\mathrm{PB}$ & 0.085 & $0.248^{* * *}$ & $0.406^{* * *}$ & $0.246^{* * *}$ & 0.788 & \\
\hline PE & $0.186^{* *}$ & $0.194^{* *}$ & $0.234^{* * *}$ & $0.231^{* * *}$ & $0.600^{* * *}$ & 0.738 \\
\hline
\end{tabular}

${ }^{\star} p<0.05,{ }^{* *} p<0.001,{ }^{* * *} p<0.001$

Source: Own elaboration. 
reliability (CR) values greater than 0.7 . Thus, the 35 items used measure in a consistent and reproducible way the characteristics of interest of the information asymmetry in the real estate market. The AVE values in the four dimensions of the scale present values greater than 0.5 , which according to Hair et al. (2014) indicates adequate convergent validity. Based on the AVE, MSV, and ASV parameters, it is verified that in all factors, the AVE value is greater than the values of the MSV and ASV parameters and that the square root of the AVE parameter (in bold in the bottom part of Table 3) is always greater than the inter-dimensional correlations. Therefore, there is evidence of convergent and discriminant validity.

The existence of positive correlations between all the factors of the information asymmetry in the Portuguese real estate market is also highlighted. The strongest correlations occur between Positive Externalities and Proximity to Businesses $(r=0.60)$ and between Housing Quality and Proximity to Businesses $(r=0.41)$, which are classified as strong and moderate, respectively (Marôco, 2018).

\section{Conclusions}

By reviewing the literature, 56 variables were obtained that characterise the information asymmetry in the real estate market. When the scale was validated for the Portuguese population, some variables were eliminated and only 35 variables remained and were distributed into six factors, which present adequate levels of validity and reliability. Thus, the information that estate agents provide to potential buyers is given by six factors, called Negative Externalities, Possibilities of a Deal, Housing Quality, Service Areas, Proximity to Businesses, and Positive Externalities. Negative externalities are characterized by the information given about contaminated surrounding lands, solid waste incineration, higher-than-average air pollution, proximity to a sewage treatment plant, overhead powerlines, landfills, degraded parks, and traffic noise. The factor Possibilities of a Deal is identified by the agents' preferences for making deals on a used property, a new property, with young or middle-aged clients, with clients looking for a cheap property, with those looking for a high-quality property, with clients who resort to credit, with those who know the market, with people who live near and with people who live far from the purchase area.

Housing quality is characterized by the information given about the structural safety of the building, the building safety project, the building's common areas, the efficiency and maintenance of the facilities, and the property's energy costs. The factor Service Areas is identified by the information given on the areas of the kitchen, sunroom, balcony, bathrooms, garage, and storage space. Proximity to Businesses is characterized by the information given about proximity to a pharmacy, bar/ restaurant, bank, and supermarket. The aforementioned Positive Externalities are related to the information given on sea, mountain, and square/street views.

This study can help academics, researchers, and professionals to better understand the factors of information asymmetry in the real estate market. The results deserve the attention of real estate agents, to inform their future clients better. This study also suggests that there should be regulations in Portugal so that every listed property has an evaluation report that is given to the buyer and duly explained following the precepts of the real estate market.

This study was based on estate agents. Therefore, its main limitation is the fact that some segments of the housing market are not characterized, nor are the buyers per type of dwelling and income. Hence, in future studies, this information should be explored, since, in wealthier segments and more exclusive areas, the information asymmetry could be different.

In the future, we recommend analysing segments that characterize the profile of the estate agent regarding the information conveyed to future house buyers. For future studies, it is important to include in the questionnaire more items related to the building's rest or leisure areas and construction quality.

\section{References}

AGARWAL, S., HE, J., SING, T. F., \& SONG, C. (2019). Do real estate agents have information advantages in housing markets? Journal of Financial Economics, 134(3), 715-735. https://doi.org/10.1016/j.jfineco.2019.05.008

ANDRÉ, C., GUPTA, R., \& MWAMBA, J. W. M. (2019). Are housing price cycles asymmetric? Evidence from the US States and Metropolitan areas. International Journal of Strategic Property Management, 23(1), 1-22. https://doi.org/10.3846/ijspm.2019.6361

AYDIN, E., BROUNEN, D., \& KOK, N. (2018). Information Asymmetry and Energy Efficiency: Evidence from the Housing Market. Maastricht University Working 
Paper, 2017. Retrieved from: https://sustainable-finance.nl/ upload/researches/Aydin-Et-Al-Information-Asymmetry.pdf

BEN-SHAHAR, D., \& GOLAN, R. (2019). Improved information shock and price dispersion: A natural experiment in the housing market. Journal of Urban Economics, 112, 70-84. https://doi.org/10.1016/j.jue.2019.05.008

BUI, T. (2020). A study of factors influencing the price of apartments: Evidence from Vietnam. Management Science Letters, 10(10), 2287-2292. doi: 10.5267/j.msl.2020.3.007

CANEPA, A., \& CHINI, E. Z. (2016). Dynamic asymmetries in house price cycles: A generalized smooth transition model. Journal of Empirical Finance, 37, 91-103. https://doi.org/10.1016/j.jempfin.2016.02.011

CARLINO, G. A., \& SAIZ, A. (2019). Beautiful city: Leisure amenities and urban growth. Journal of Regional Science, 59(3), 369-408. https://doi.org/10.1111/jors. 12438

CHEN, W. Y. \& LI, X. (2017). Cumulative impacts of polluted urban streams on property values: A 3-D spatial hedonic model at the micro-neighborhood level. Landscape and Urban Planning, 162, 1-12. https://doi. org/10.1016/j.landurbplan.2017.01.012

CHEN, W. Y., LI, X., \& HUA, J. (2019). Environmental amenities of urban rivers and residential property values: A global meta-analysis. Science of the Total Environment, 693(13), 133628. DOI: 10.1016/j.scitotenv.2019.133628

CHENG, P., LIN, Z., \& LIU, Y. (2019). Price Discovery with Heterogeneous Sellers in Real Estate. Journal of Real Estate Research. (Accepted) Retrieved from: https:// www.researchgate.net/publication/333755774_Price_ Discovery_with_Heterogeneous_Sellers_in_Real_Estate

DALMORO, M., \& VIEIRA, K. M. (2013). Dilemmas of the type Likert scales construction: does the number of items and the disposition influence results? Revista Gestão Organizacional, 6(3), 161-174.

DONNER, H., \& KOPSCH, F. (2018). Housing Tenure and Informational Asymmetries. Journal of Real Estate Research, 40(2), 155-177. https://doi.org/10.5555/08965803.40.2.155

FORNELL, C. \& LARCKER, D. F. (1981). Evaluating structural equation models with unobservable variables and measurement error. Journal of Marketing Research, $18,39-50$.

GARMAISE, M. J., \& MOSKOWITZ, T. J. (2004). Confronting information asymmetries: Evidence from real estate markets. The Review of Financial Studies, 17(2), 405-437.

HAIR, J. F., BLACK, W. C., BABIN, B. J. \& ANDERSON, R. E. (2014). Multivariate Data Analysis (7th ed.). Pearson, Edinburgh.

HONG, S. H. (2020). Quantifying Agent Manipulations in Housing Search. Working paper. University of Illinois, Urbana-Champaign. Retrieved from: http://faculty.las. illinois.edu/hyunhong/agent_influence.pdf

Instituto Nacional de Estatística (2018). Estatísticas da Construção e Habitação - 2018. Lisbon. Retrieved from: https://www.ine.pt/xportal/xmain?xpid=INE\&xpgid=ine_ publicacoes\&PUBLICACOESpub_boui=382303539\& PUBLICACOESmodo $=2 \& \mathrm{xlang}=\mathrm{pt}$

JENSEN, C. U., PANDURO, T. E., LUNDHEDE, T. H., NIELSEN, A. S. E., DALSGAARD, M. \& THORSEN, B. J. (2018). The impact of on-shore and off-shore wind turbine farms on property prices. Energy policy, 116, 50-59. Retrieved from http://macroecointern. dk/pdf-reprints/Jensen_EP_2018.pdf

KLINE, R. B. (2015). Principles and Practice of Structural Equation Modeling (4th ed.). New York: Guilford Press.

KURLAT, P., \& STROEBEL, J. (2015). Testing for information asymmetries in real estate markets. The Review of Financial Studies, 28(8), 2429-2461. https:// doi.org/10.1093/rfs/hhv028

LEVITT, S. D., \& SYVERSON, C. (2008). Market distortions when agents are better informed: The value of information in real estate transactions. The Review of Economics and Statistics, 90(4), 599-611. https://doi. org/10.1162/rest.90.4.599

LEVY, D. S., FRETHEY-BENTHAM, C., \& CHEUNG, W. K. S. (2020). Asymmetric framing effects and market familiarity: experimental evidence from the real estate market. Journal of Property Research, 37(1), 85-104. https:// doi.org/10.1080/09599916.2020.1713858 
LI, L. \& CHAU, K. (2019). Information Asymmetry with Heterogeneous Buyers and Sellers in the Housing Market. Retrieved from SSRN: https://ssrn.com/abstract=3364126 or http://dx.doi.org/10.2139/ssrn.3364126

MARÔCO, J. \& GARCIA-MARQUES, T. (2006). Qual a fiabilidade do alfa de Cronbach? Questóes antigas e soluçōes modernas? Laboratório de Psicologia, 4(1), 65-90.

MARÔCO, J. (2014). Análise de equaçōes estruturais: Fundamentos teóricos, Software \& Aplicaçóes (2nd ed.). Lisbon, Portugal: ReportNumber.

MARÔCO, J. (2018). Análise Estatística com o SPSS Statistics 25 (7th ed.). Lisbon, Portugal: ReportNumber.

MOHAMMADI, A. R., TAHIR, M. M., USMAN, I. M. S., SURAT, M., \& ISMAIL, A. H. (2010). The effect of balcony to enhance the natural ventilation of terrace houses in the tropical climate of Malaysia. The Journal of Design+ Built, 3, 105-113.

NASSER, A. A. M. (2017). Valor das externalidades urbanas: uma análise à luz do mercado imobiliário paulistano. Master's dissertation. Insper Instituto de Ensino e Pesquisa. Retrieved from URI: http://hdl.handle.net/11224/2261

PESTANA, M. H. \& GAGEIRO J. N. (2014). Análise de dados em Ciências Sociais - A complementaridade do SPSS (6th ed.). Lisbon: Sílabo.

PUY, D., ARI, A., \& SHI, Y. (2020). Foreign Demand and Local House Prices: Evidence from the US (No. 20/43). International Monetary Fund. IMF Working Paper. Research Department. Retrieved from: https://www.imf.org/en/ Publications/WP/Issues/2020/02/28/Foreign-Demandand-Local-House-Prices-Evidence-from-the-US-49028

QIU, L., TU, Y., \& ZHAO, D. (2020). Information asymmetry and anchoring in the housing market: a stochastic frontier approach. Journal of Housing and the Built Environment, 35, 573-591. https://doi.org/10.1007/s10901-019-09701-y
SAYDOMETOV, S., SABHERWAL, S., \& AROUL, R. R. (2020). Sentiment and its asymmetric effect on housing returns. Review of Financial Economics, 00, 1-21. https://doi.org/10.1002/rfe.1097

SCHUMACKER, R. E., \& LOMAX, R. G. (2004). A beginner's guide to structural equation modeling (2nd ed.). Mahwah, N. J.: Lawrence Erlbaum Associates.

STROEBEL, J. (2016). Asymmetric information about collateral values. The Journal of Finance, 71(3), 1071-1112. https://doi.org/10.1111/jofi.12288

TAVARES, F. O. (2011). Avaliação imobiliária: entre a ciência da avaliação e a arte da apreciação. $\mathrm{PhD}$ Thesis in Management, Universidade de Aveiro.

TAVARES, F. O.; MOREIRA, A. C. e PEREIRA, E.T. (2013). Assimetria de Informação no Mercado Imobiliário em Portugal. Revista de Administração da UNIMEP, 11(3), 196-220.

TAVARES, F.O.; MOREIRA, A. C. \& PEREIRA, E. T. (2012). Assimetria de Informação no Mercado Imobiliário: uma revisão da literatura. Revista Universo Contábil, 8(2), 146-164. doi:10.4270/ruc.2012218

WALLS, M., MAGLIOCCA, N., \& MCCONNELL, V. (2018). Modeling coastal land and housing markets: Understanding the competing influences of amenities and storm risks. Ocean \& Coastal Management, 157, 95 110. https://doi.org/10.1016/j.ocecoaman.2018.01.021

WANG, S.; ZENG, Y.; YAO, J. \& ZHANG, H. (2020). Economic policy uncertainty, monetary policy, and housing price in China. Journal of Applied Economics, 23(1),235252. https://doi.org/10.1080/15140326.2020.1740874

WIT, E. R., \& KLAAUW, B. (2013). Asymmetric information and list-price reductions in the housing market. Regional Science and Urban Economics, 43(3), $507-$ 520. https://doi.org/10.1016/j.regsciurbeco.2013.03.001

\section{Financial support:}

Name of the funding agency /OR/ There are no funding agencies to report.

\section{Conflicts of interest:}

The authors have no conflict of interest to declare. 


\section{Copyrights:}

RBGN owns the copyrights of this published content.

\section{Plagiarism analysis:}

RBGN performs plagiarism analysis on all its articles at the time of submission and after approval of the manuscript using the iThenticate tool.

\section{Authors:}

1. Fernando Tavares, Doctor in Corporate Strategic and Economic Analysis, University of Vigo, Vigo, Spain.

E-mail. ftavares@iscet.pt

2. Eulália Mota Santos, Doctor in Mathematics, University of Aveiro, Aveiro, Portugal

Email: eulalia.santos@ipleiria.pt

\section{Authors' Contributions:}

$1^{\text {st }}$ author: Definition of research problem; Development of hypotheses or research questions (empirical studies); Development of theoretical propositions (theoretical work); Definition of methodological procedures; Data Collection; Literature review; Statistical analysis; Analysis and interpretation of data; Critical revision of the manuscript; Manuscript writing.

$2^{\text {nd }}$ author: Development of hypotheses or research questions (empirical studies); Development of theoretical propositions (theoretical work); Definition of methodological procedures; Data Collection; Literature review; Statistical analysis; Analysis and interpretation of data; Critical revision of the manuscript; Manuscript writing. 